\title{
Statherian (ca. 1714-1680 Ma) Extension-Related Magmatism and Deformation in the Southwestern Korean Peninsula and Its Geological Significance: Constraints from the Petrological, Structural, Geochemical and Geochronological Studies of Newly Identified Granitoids
}

\author{
Byung Choon Lee, Weon-Seo Kee *, Uk Hwan Byun and Sung Won Kim
}

check for updates

Citation: Lee, B.C.; Kee, W.-S.; Byun, U.H.; Kim, S.W. Statherian (ca. 1714-1680 Ma) Extension-Related Magmatism and Deformation in the Southwestern Korean Peninsula and Its Geological Significance: Constraints from the Petrological, Structural, Geochemical and Geochronological Studies of Newly Identified Granitoids. Minerals 2021, 11, 557. https://doi.org/10.3390/ $\min 11060557$

Academic Editor: Dominique Gasquet

Received: 15 April 2021

Accepted: 21 May 2021

Published: 24 May 2021

Publisher's Note: MDPI stays neutral with regard to jurisdictional claims in published maps and institutional affiliations.

Copyright: (c) 2021 by the authors. Licensee MDPI, Basel, Switzerland. This article is an open access article distributed under the terms and conditions of the Creative Commons Attribution (CC BY) license (https:// creativecommons.org/licenses/by/ $4.0 /)$.
Geology Division, Korea Institute of Geoscience and Mineral Resources, Daejeon 34132, Korea; lbc@kigam.re.kr (B.C.L.); buh@kigam.re.kr (U.H.B.); sungwon@kigam.re.kr (S.W.K.)

* Correspondence: wskee@kigam.re.kr

\begin{abstract}
In this study, petrological, structural, geochemical, and geochronological analyses of the Statherian alkali feldspar granite and porphyritic alkali feldspar granite in the southwestern part of the Korean Peninsula were conducted to examine petrogenesis of the granitoids and their tectonic setting. Zircon $\mathrm{U}-\mathrm{Pb}$ dating revealed that the two granites formed around $1.71 \mathrm{Ga}$ and $1.70-1.68 \mathrm{Ga}$, respectively. The results of the geochemical analyses showed that both of the granites have a high content of $\mathrm{K}_{2} \mathrm{O}, \mathrm{Nb}$, Ta, and $\mathrm{Y}$, as well as high $\mathrm{FeO}^{\mathrm{t}} / \mathrm{MgO}$ and $\mathrm{Ga} / \mathrm{Al}$ ratios. Both granites have alkalicalcic characteristics with a ferroan composition, indicating an A-type affinity. Zircon Lu-Hf isotopic compositions yielded negative $\varepsilon_{\mathrm{Hf}}{ }^{(t)}$ values $(-3.5$ to -10.6$)$, indicating a derivation from ancient crustal materials. Both granite types underwent ductile deformation and exhibited a dextral sense of shear with a minor extension component. Based on field relationships and zircon U-Pb dating, it was considered that the deformation event postdated the emplacement of the alkali feldspar granite and terminated soon after the emplacement of the porphyritic alkali feldspar granite in an extensional setting. These data indicated that there were extension-related magmatic activities accompanying ductile deformation in the southwestern part of the Korean Peninsula during 1.71-1.68 Ga. The Statherian extension-related events are well correlated with those in the midwestern part of the Korean and eastern parts of the North China Craton.
\end{abstract}

Keywords: Korean Peninsula; Statherian; igneous activity; deformation; extension

\section{Introduction}

The Wilson cycle [1] is closely associated with the formation and destruction of orogenic belts and related cratonic blocks. The North China Craton (NCC), one of the largest cratonic blocks in northeast Asia, is divided into eastern and western blocks, and it is generally accepted that the eastern block has retained the changes that occurred during the Wilson cycle-like evolution during the Paleoproterozoic (2.12-1.67 Ga) [2-5]. Although there is still a debate on the tectonic setting for the initial stage of the Wilson cycle-like evolution [3], it could be marked by the opening of the ocean together with intraplate magmatism between the Longgang Block in the eastern part of the NCC and the Nangnim Massif in the Korean Peninsula at ca. 2.12 Ga [6]. These events were followed by the subduction, continental collision, as well as post-collisional magmatic, sedimentary, metamorphic, and deformation events relating to the formation and destruction of the Jiao-Ji mobile belt during 1.95-1.67 Ga [3-5,7].

The last stage of the Wilson cycle-like evolution in the eastern part of the NCC, including the Korean Peninsula, is characterized by the occurrence of extension-related magmatism, sedimentation, and regional anatexis $[4,8,9]$. The extension-related mag- 
matism has produced igneous rocks that have mafic to felsic bimodal compositions in the northwestern area of the eastern part of the NCC [10-14], the southern part of the NCC [8,15], and the western part of the Nangnim and Gyeonggi massifs in the Korean Peninsula $[9,16]$ during 1.80-1.60 Ga. Integrated geochemical studies suggest that igneous rocks were formed in post-orogenic and/or anorogenic settings after the continental collision $[8,14]$. It was recently identified that the southwestern part of the Korean Peninsula also underwent the late Paleoproterozoic (1.71-1.68 Ga) magmatism and deformation [17]. It is well known that the understanding of the nature of granitoids can provide critical information about the tectonic setting. The late Paleoproterozoic (Statherian) magmatism and deformation in the eastern part of the NCC is one of the key factors in interpreting the tectonic evolution of northeast Asia. Similarly, the late Paleoproterozoic magmatism and deformation in the southwestern part of the Korean Peninsula can also provide the crucial information needed to understand the tectonic evolution of northeast Asia.

In this study, whole-rock geochemical, zircon U-Pb, and Lu-Hf analyses were conducted on the newly identified granitoids from the southwestern region of the Korean Peninsula to decipher their emplacement timing and trace their origin and petrogenesis. The structural analysis of the granitoids was also conducted to shed light on the structural geometry and kinematics of the late Paleoproterozoic. Based on the data obtained from the current and previous studies, the extension-related magmatism and deformation in the western part of the Korean Peninsula were correlated with those in the eastern NCC and the Yangtze Block in the South China Craton, and the geological relationships between them were discussed.

\section{General Geology and Petrography}

The basement of the Korean Peninsula is divided into four Precambrian tectonic provinces (Kwanmo, Nangnim, Gyeonggi, and Yeongnam massifs) and is mainly composed of Paleoproterozoic (Orosirian) para- and orthogneisses with minor Archean remnants [18,19] (Figure 1a). The early Orosirian paragneisses formed after $2.0 \mathrm{Ga}$ and were intruded by orthogneisses during 2.00-1.80 Ga [20-23]. The para- and orthogneisses underwent upper amphibolite to granulite facies metamorphism during 1.88-1.86 Ga [24-26]. These Paleoproterozoic magmatic and metamorphic events are considered to be closely related to the amalgamation and breakup of the Columbia supercontinent [27]. The Paleoproterozoic rocks formed during the Orosirian Period are covered by Statherian sedimentary rocks (Seosan Group) and then intruded by Statherian granitoids $[9,16,28]$. Recently, it has been suggested that the Statherian granitoids in the midwestern part of the Korean Peninsula (western part of the Gyeonggi Massif) are $A_{2}$-type granites formed in a post-collisional setting [9].

The study area (Sangtaedo-Jungtaedo-Hataedo-Ganseodo), located in the southwestern part of the Korean Peninsula, consists of quartz schist, foliated alkali feldspar granite, foliated porphyritic alkali feldspar granite, conglomerate, and dikes (Figure 1) [17]. Based on field relationships, the quartz schist preserved as xenolith in the foliated alkali feldspar granite is considered to be the oldest geological unit in the study area, although its depositional age is not constrained. The foliated alkali feldspar granite (AFG) is exposed in the regions of Hataedo, Jungtaedo, and the southern part of Sangtaedo and is intruded by the foliated porphyritic alkali feldspar granite (PAFG), which is exposed in the region of Sangtaedo, northwestern part of Jungtaedo, and Ganseodo (Figure 1). The AFG is unconformably overlain by the Cretaceous conglomerate. The Cretaceous conglomerate in the western part of Hataedo is a massive, clast-supported conglomerate. Various types of Cretaceous undeformed dikes (mafic, intermediate, and acidic compositions) have intruded the AFG and PAFG. 

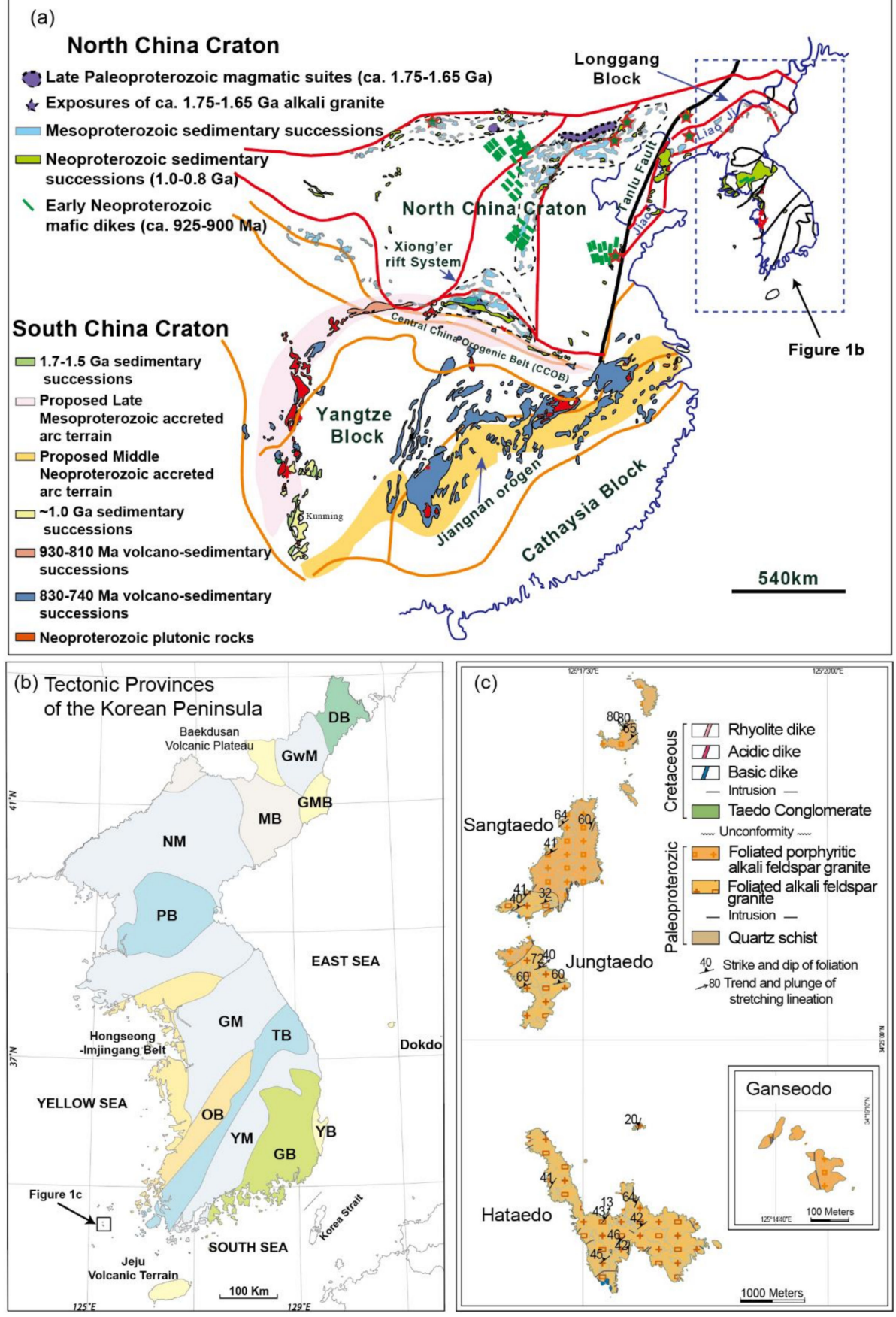

Figure 1. (a) Simplified tectonic map of northeast Asia (modified after [29]); (b) Simplified tectonic provinces of the Korean Peninsula [18]. (c) 1:50,000 scale Geological map of the Sangtaedo-JungtaedoHataedo-Ganseodo area [17]. Abbreviations: DB—Dumangang Belt, GwM-Gwanmo Massif, GMBGilju-Myeongcheon Basin, MB-Macheollyeong Belt, NM-Nangnim Massif, PB-Pyeongnam Basin, GM-Gyeonggi Massif, OB-Okcheon Belt, TB—Taebaeksan Basin, YM-Yeongnam Massif, GBGyeongsang Basin, YB-Yeonil Basin.

\section{Analytic Methods}

\subsection{Zircon $\mathrm{U}-\mathrm{Pb}$ Analyses}

The zircon grains were separated from the AFG and PAFG by standard crushing, water-based panning, magnetic separation, and heavy liquid separation techniques, and the separated zircon grains were mounted together with SL13 $(\mathrm{U}=238 \mathrm{ppm})$ and FC-1 standards $\left({ }^{206} \mathrm{~Pb}^{*} /{ }^{238} \mathrm{U}=0.1859 ; 1099 \mathrm{Ma}\right)$ to calibrate the $\mathrm{U}$ contents and $\mathrm{Th} / \mathrm{U}$ ratios. The 
FC-1 standard zircon yielded a weighted-mean age of $1099 \pm 9.5 \mathrm{Ma}(\mathrm{MSWD}=1.73, n=55)$, which was consistent with the recommended value. The internal texture of zircon was documented by cathodoluminescence (CL) using a JEOL JSM-6610LV scanning electron microscope at the Korea Basic Science Institute (KBSI) Ochang, Korea. The U-Th-Pb isotopes in zircon grains were measured using a sensitive high-resolution ion microprobe (SHRIMP IIe/MC instrument) at KBSI. The primary oxygen beam was accelerated at $10 \mathrm{kV}$ and focused to a spot diameter of approximately $25 \mu \mathrm{m}$. Each U-Pb analysis involved five scans in the mass range of 196-254 AMU. The $U$ and Th concentrations were determined relative to those of the SL13 standard zircon. The measured ${ }^{206} \mathrm{~Pb} /{ }^{238} \mathrm{U}$ ratios were calibrated using an FC-1 standard zircon. A common $\mathrm{Pb}$ correction was conducted using the ${ }^{204} \mathrm{~Pb}$ correction method [30]. The detailed procedure and review of U-Th-Pb dating of zircon using SHRIMP are given by [31]. The obtained data were processed using SQUID 2.50 and Isoplot 3.75 [32]. The uncertainties for ages and ratios are given at the $1 \sigma$ level, whereas uncertainties for weighted-mean ages are given at the $2 \sigma$ level.

\subsection{Zircon Lu-Hf Analyses}

The zircon Lu-Hf isotope analyses were conducted using laser ablation-multicollectorinductively coupled plasma-mass spectrometry (LA-MC-ICP-MS) employing an ESI NWR193UC LA system attached to a Nu Plasma II MC-ICP-MS instrument at the KBSI, Ochang, Korea. Laser energy of approximately $5 \mathrm{~J} / \mathrm{cm}^{2}$, a laser spot size of $45 \mu \mathrm{m}$, and a repetition rate of $20 \mathrm{~Hz}$ were used during the analysis. The interference of ${ }^{176} \mathrm{Yb}$ and ${ }^{176} \mathrm{Lu}$ on ${ }^{176} \mathrm{Hf}$ was corrected by measuring the intensity of the interference-free ${ }^{173} \mathrm{Yb}$ and ${ }^{175} \mathrm{Lu}$ isotopes. The 91,500 and FC-1 standard zircons were analyzed to monitor the accuracy of the ${ }^{176} \mathrm{Hf} /{ }^{177} \mathrm{Hf}$ ratios. The 91,500 and FC-1 zircons yielded weighted-mean ${ }^{176} \mathrm{Hf} /{ }^{177} \mathrm{Hf}$ ratios of $0.282298 \pm 0.00001(\mathrm{~N}=61 ; 2 \sigma)$ and $0.282177 \pm 0.000015(\mathrm{~N}=27 ; 2 \sigma)$. The analytical procedure and data acquisition are described in detail in [20]. The ${ }^{176} \mathrm{Lu}$ decay constant $\left(1.867 \times 10^{-11} \mathrm{y}^{-1}\right.$; [33]), depleted mantle $\left({ }^{176} \mathrm{Lu} /{ }^{177} \mathrm{Hf}=0.0384\right.$ and $\left.{ }^{176} \mathrm{Hf} /{ }^{177} \mathrm{Hf}=0.28325 ;[34]\right)$ and chondrite $\left({ }^{176} \mathrm{Lu} /{ }^{177} \mathrm{Hf}=0.0332\right.$ and ${ }^{176} \mathrm{Hf} /{ }^{177} \mathrm{Hf}=0.282772 ;$ [35]) values were used to calculate the $\varepsilon_{\mathrm{Hf}}{ }^{(\mathrm{t})}$ values and model ages $\left(\mathrm{T}_{\mathrm{DM} 1}\right)$. The average continental crustal composition $\left({ }^{176} \mathrm{Lu} /{ }^{177} \mathrm{Hf}=0.015 ;[36]\right)$ was used to calculate the two-stage crustal model ages $\left(\mathrm{T}_{\mathrm{DM} 2}\right)$.

\subsection{Whole-Rock Geochemistry}

The AFG and PAFG samples were crushed into $<0.5 \mathrm{~cm}$ fragments in a tungsten carbide mortar and powdered in an agate ball mill. The crushed samples were pulverized to pass through a 200-mesh sieve to ensure homogeneity. The concentrations of major and trace elements were measured by inductively coupled plasma atomic emission spectrometry (ICP-AES; ThermoJarrel-Ash ENVRIO II) and inductively coupled plasma-mass spectrometry (ICP-MS; Perkin Elmer Sciex Elan 9000) at Activation Laboratories, Ancaster, ON, Canada. The major elements were measured with international reference materials, including NIST 694, DNC-1, W-2a, SY-4, and BIR-1, and the detection limits of major elements were $0.01 \%$. The trace elements were measured with international reference materials, including SDC-1, TDB-1, SY-4, and ZW-C, and the detection limits of trace elements were $0.002-0.01 \mathrm{ppm}$. More detailed analytical processes and conditions are provided in http:/ / www.actlabs.com/ (accessed on 23 May 2021).

\section{Results}

\subsection{Petrography and Structural Analysis}

The AFG is generally medium- to coarse-grained and is characterized by augenshaped alkali feldspar megacrysts $3-5 \mathrm{~cm}$ in size $(7 \mathrm{~cm}$ maximum) aligned parallel to the regional mylonitic foliation (Figure 2). The AFG consists of alkali feldspar phenocrysts together with alkali feldspar, biotite, quartz, and plagioclase (Figure 3a,b). The PAFG is medium- to coarse-grained and is characterized by pale, reddish-colored alkali feldspar phenocrysts ranging in size from 1 to $3 \mathrm{~cm}$ (Figure 4). The PAFG consists of alkali feldspar 
phenocrysts embedded in a fine-grained matrix composed of alkali feldspar, quartz, biotite, and plagioclase (Figure 3c,d).
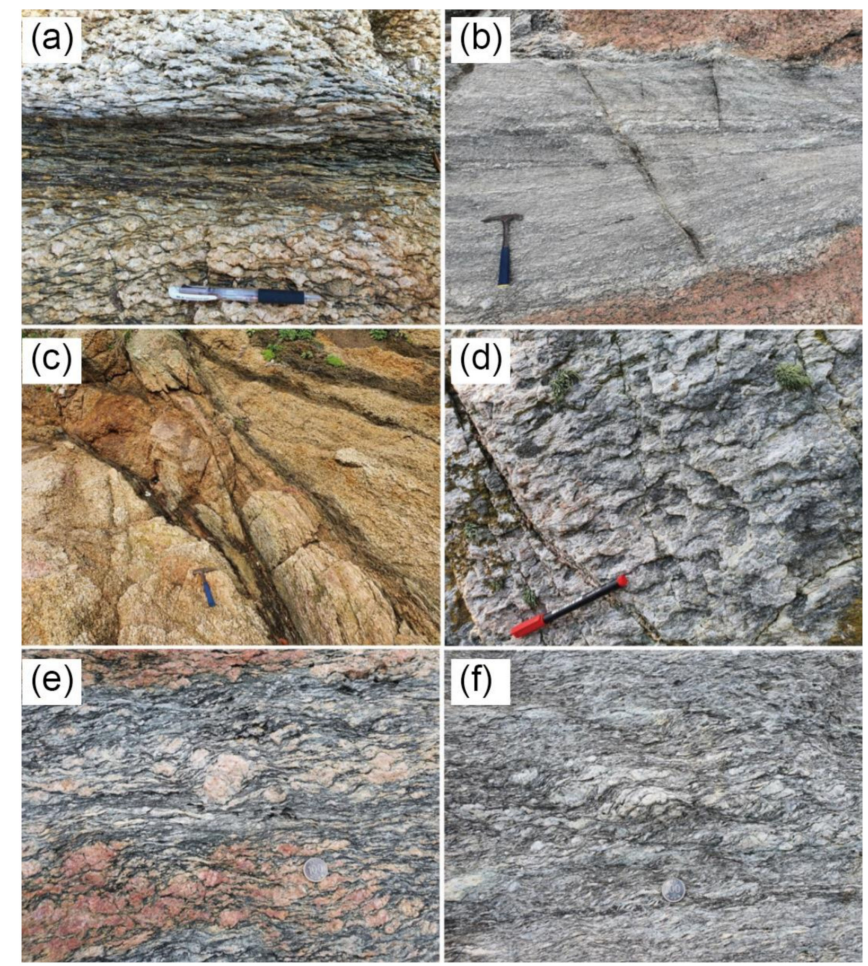

Figure 2. Outcrop photographs of the alkali feldspar granite (AFG). (a,b) Discrete shear zones, mainly composed of ultralmylonite. (c) Anastomosing shear zones surrounding lenses of weakly deformed AFG. (d) Gently plunging lineation on mylonitic foliation plane. (e,f) Kinematic indicators with a dextral sense of shear, including shear bends, $\sigma$-type alkali feldspar porphyroclasts, and S/C-composite fabrics.

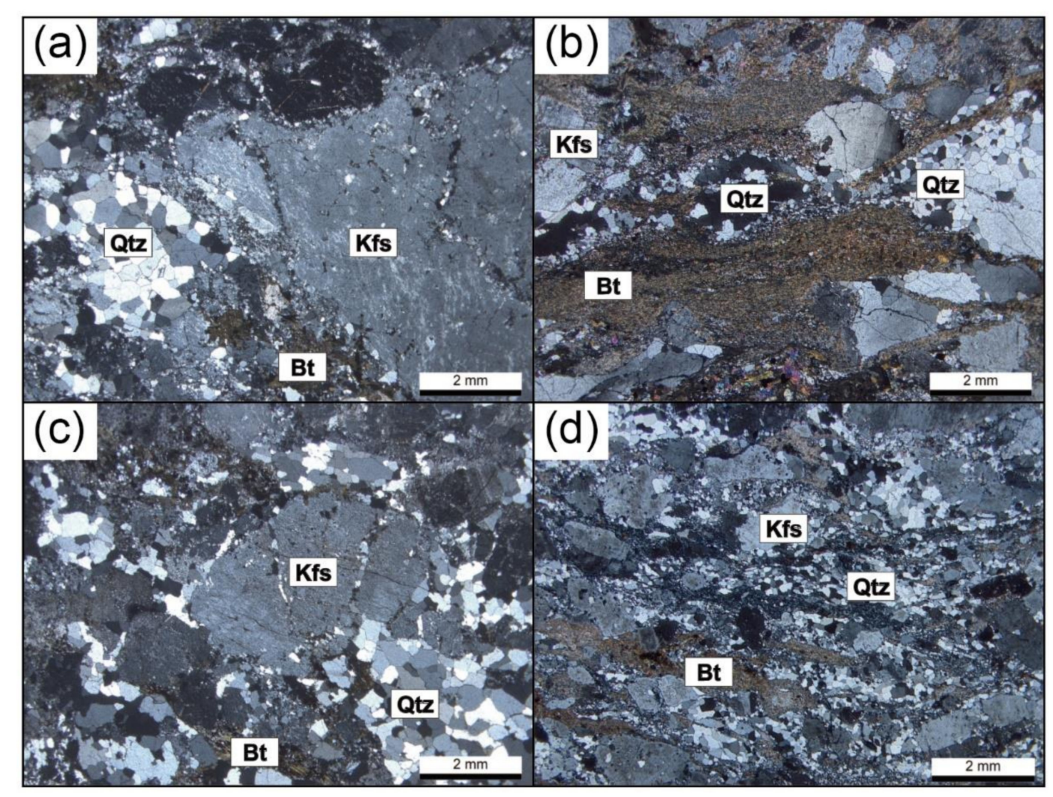

Figure 3. Photomicrograph of the AFG $(\mathbf{a}, \mathbf{b})$ and porphyritic alkali feldspar granite (PAFG; $\mathbf{c}, \mathbf{d})$. Abbreviations: Kfs-K-feldspar, Bt-Biotite, Qtz-Quartz. 


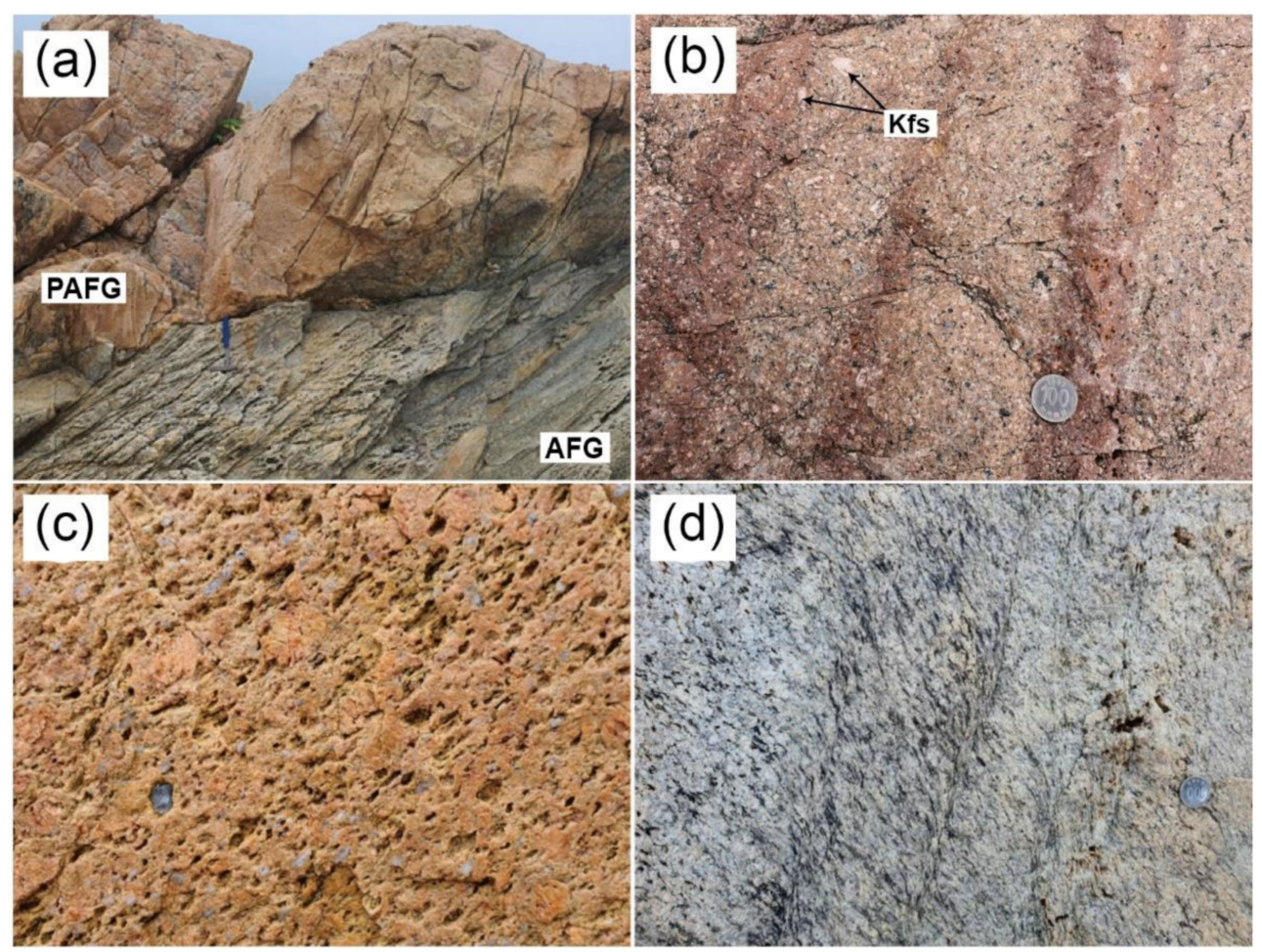

Figure 4. Outcrop photographs of the PAFG. (a) Intrusive contact relationship between the PAFG and AFG. (b) Porphyritic texture developed in the PAFG. (c,d) Minor continuous shear zones with a dextral sense of shear. Abbreviations: Kfs-K-feldspar.

The Paleoproterozoic AFG and PAFG were mostly affected by ductile shearing parallel to the regional shear zones. The regional extension of the shear zone was unclear because of its occurrence in isolated island areas. The deformation degree of the AFG was much stronger than that of the PAFG, and abrupt transitions from protomylonite to ultramylonite were frequently observed. The highly strained zones in the AFG occurred as discrete shear zones, which were mainly composed of ultramylonite. The discrete shear zones had various widths ranging from a few centimeters to several meters and locally showing patterns of anastomosing shear zones surrounding lenses of weakly deformed granite (Figure 2a-c). The discrete shear zones showed a low to subvertical dip angle. The mylonitic foliation stroke NE-ENE and dipped to the NW (Figure 5). The stretching lineation mainly plunged gently to the NE (Figure 2d). Kinematic indicators, including S-C fabrics, shear bands, and asymmetric porphyroclast systems of rounded alkali feldspar, consistently showed a dextral sense of shear (Figure 2e,f). These structural features indicate that dextral strike-slip movement with a minor extensional component (southeast side up) was dominant in the shear zone. The PAFG, which intrudes into the AFG, was also pervasively foliated but was less deformed compared to the AFG (Figure 4c,d). The highly strained zone in the PAFG was less frequent and was characterized by a very thin ultramylonite zone, several millimeters wide. The overall attitude of mylonitic foliation in the PAFG was parallel to that in the AFG, and the sense of shear was also dextral, as indicated by the geometry of the minor continuous shear zones (Figure $4 \mathrm{~d}$ ).

\subsection{Zircon $\mathrm{U}-\mathrm{Pb}$ and Lu-Hf Analyses}

Zircon grains from the TD12 sample (AFG) were euhedral to subhedral and coarse-grained $(>200 \mu \mathrm{m})$. In the cathodoluminescence (CL) image, most of the zircon grains showed concentricor faint-zoned cores partly rimmed by dark unzoned domains (Figure 6a). The zircon cores had low U (19-95 ppm) and Th (15-113 ppm) contents with high Th/U ratios, ranging from 0.82 to 1.46 (Table $\mathrm{S} 1$ ). Eleven $\mathrm{U}-\mathrm{Th}-\mathrm{Pb}$ analyses yielded ${ }^{207} \mathrm{~Pb} /{ }^{206} \mathrm{~Pb}$ ages ranging from 1639 to $1742 \mathrm{Ma}$ and are concordant at $1714 \pm 12 \mathrm{Ma}(\mathrm{MSWD}=1.3$; Figure 7a). Eleven analyses of 
zircon cores gave $\varepsilon_{\mathrm{Hf}}{ }^{(t)}$ values ranging from -3.7 to -7.7 with the Neoarchean $\mathrm{T}_{\mathrm{DM} 2}$ model ages ranging from 2623 to $2874 \mathrm{Ma}$ (Figure 8a,b; Table S2).

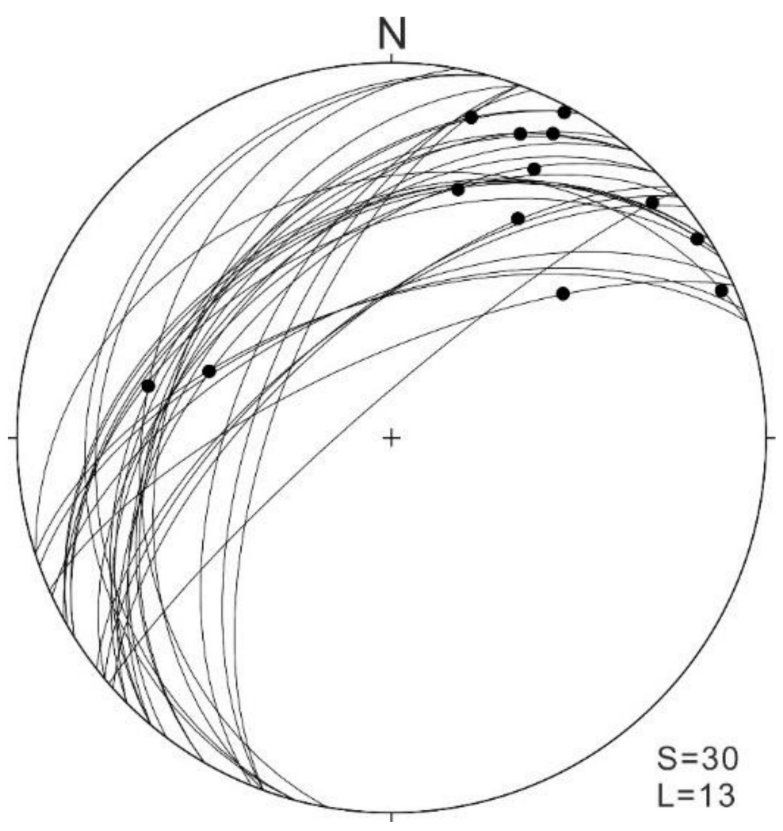

Figure 5. Lower hemisphere, equal-area stereographic projection of mylonitic foliation (great circles, S), and stretching lineation (filled circles, L) from the Paleoproterozoic granitoids.

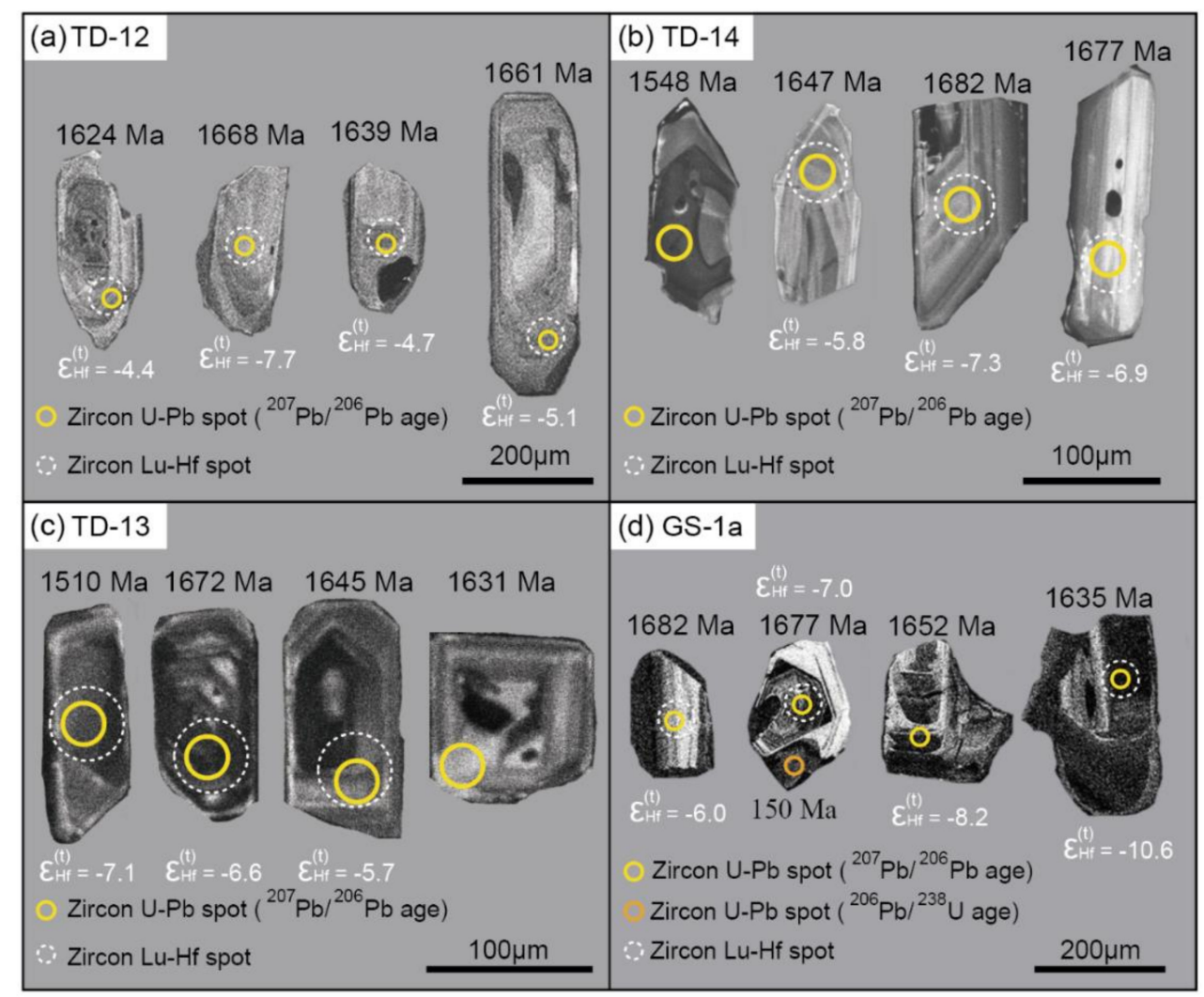

Figure 6. Zircon CL images of the AFG $(\mathbf{a}, \mathbf{b})$ and PAFG $(\mathbf{c}, \mathbf{d})$ with analyzed spots. 

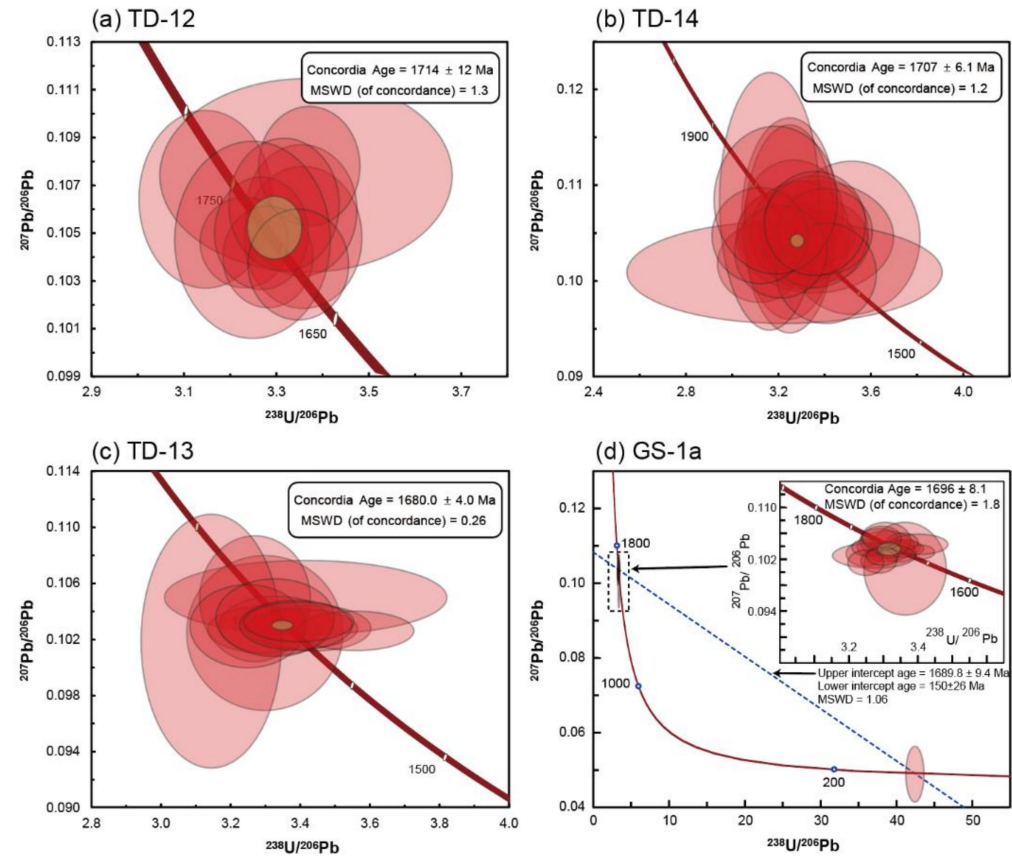

Figure 7. Tera-Wasserburg Concordia diagrams for zircon U-Pb analyses from the AFG $(\mathbf{a}, \mathbf{b})$ and PAFG $(\mathbf{c}, \mathbf{d})$.
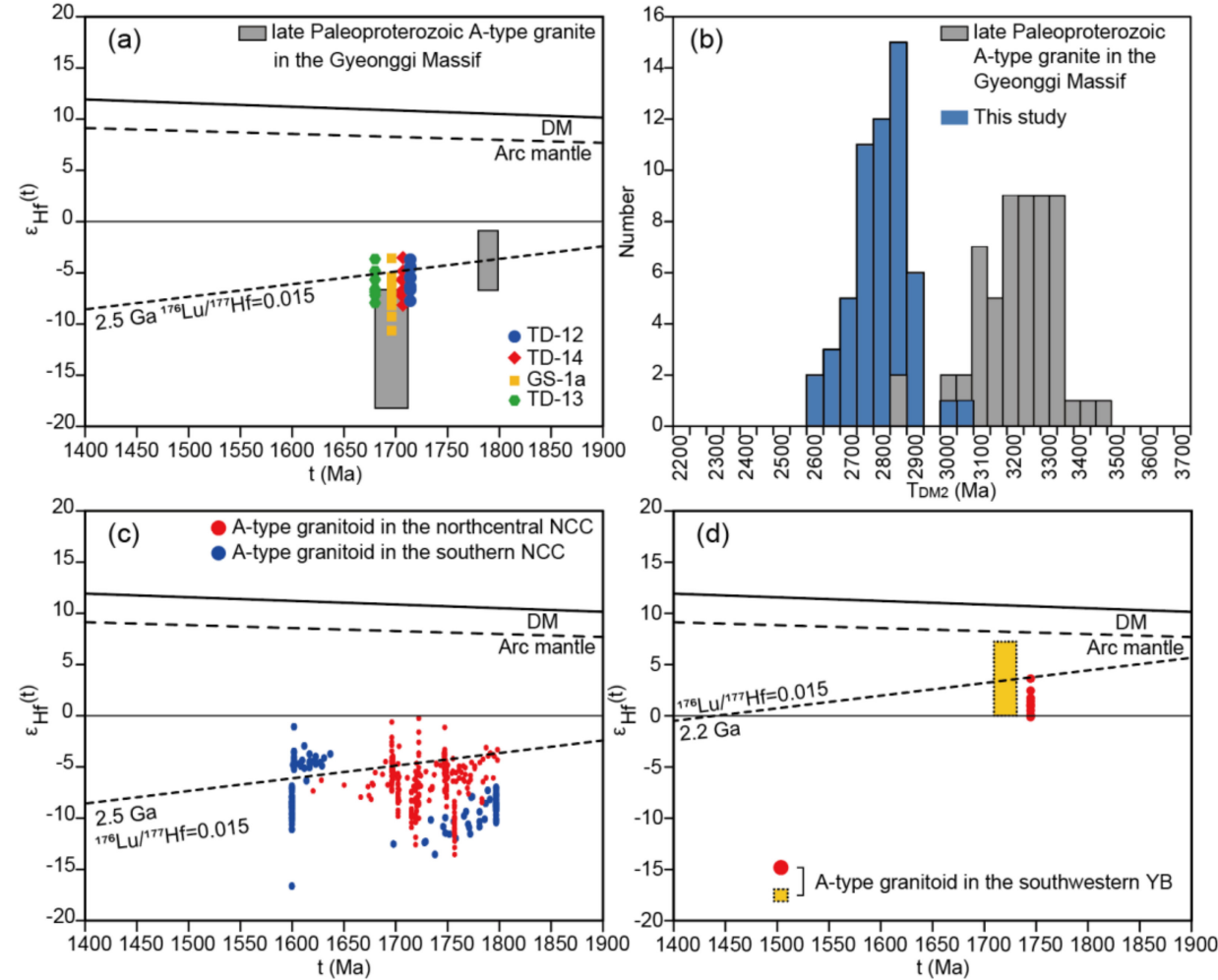

Figure 8. (a) $\varepsilon_{\mathrm{Hf}}{ }^{(\mathrm{t})}$ versus crystallization ages for the Statherian granitoids in the southwestern part of the Korean Peninsula and the Gyeonggi Massif (data collected from this study and [9]). The extrapolation of the depleted and arc mantle was made from the values suggested by [37,38]. (b) Histogram of zircon model ages (data collected from this study and [9]). (c) $\varepsilon_{\mathrm{Hf}}{ }^{(\mathrm{t})}$ versus crystallization ages for the Statherian granitoids in the eastern NCC (data collected from $[8,10,11]$, and references therein). (d) $\varepsilon_{\mathrm{Hf}}{ }^{(\mathrm{t})}$ versus crystallization ages for the Statherian granitoids in the southwestern part of the Yangtze Block (data collected from $[39,40])$. 
Zircon grains from the TD14 sample (AFG) were euhedral to subhedral and medium- to coarse-grained $(100-200 \mu \mathrm{m})$. In the CL image, most of the zircon grains showed concentric, patchy, or banded-zoned cores partly rimmed by dark unzoned domains (Figure 6b). The zircon cores had low U (14-125 ppm) and Th (12-180 ppm) contents with high Th/U ratios, ranging from 0.85 to 1.21 (Table S1). Twenty U-Th- $\mathrm{Pb}$ analyses yielded ${ }^{207} \mathrm{~Pb} /{ }^{206} \mathrm{~Pb}$ ages ranging from 1226 to $1682 \mathrm{Ma}$ and a concordance age of $1707 \pm 6.1 \mathrm{Ma}$ (MSWD = 1.2; Figure 7b). Seventeen zircon core analyses yielded $\varepsilon_{\mathrm{Hf}}{ }^{(t)}$ values ranging from -3.5 to -8.1 with the Neoarchean $\mathrm{T}_{\mathrm{DM} 2}$ model ages ranging from 2609 to $2894 \mathrm{Ma}$ (Figure 8a,b; Table S2).

Zircon grains from the TD13 sample (PAFG) were euhedral to subhedral and fine- to medium-grained $(70-120 \mu \mathrm{m})$. In the CL image, most of the zircon grains showed concentric or patchy-zoned cores (Figure 6c). The zircon cores had low to medium U (41-702 ppm) and Th (42-1205 ppm) contents with high Th/U ratios, ranging from 0.65 to 1.77 (Table S1). Thirteen $\mathrm{U}-\mathrm{Th}-\mathrm{Pb}$ analyses yielded ${ }^{207} \mathrm{~Pb} /{ }^{206} \mathrm{~Pb}$ ages ranging from 1534 to $1689 \mathrm{Ma}$ and yielded a concordance age of $1680 \pm 4.0 \mathrm{Ma}(\mathrm{MSWD}=0.26$; Figure 7c). Nine analyses of zircon cores gave $\varepsilon_{\mathrm{Hf}}{ }^{(\mathrm{t})}$ values ranging from -3.6 to -7.9 , with the Neoarchean $\mathrm{T}_{\mathrm{DM} 2}$ model ages ranging from 2596 to $2861 \mathrm{Ma}$ (Figure 8a,b; Table S2).

Zircon grains from GS1 (PAFG) were euhedral to subhedral and fine- to coarse-grained (70-250 $\mu \mathrm{m})$. In the CL image, most of the zircon grains showed concentric, patchy, or banded-zoned cores partly rimmed by dark unzoned domains (Figure 6d). The zircon cores had low U (26-254 ppm) and Th (24-251 ppm) contents with high Th/U ratios, ranging from 0.56 to 1.30 (Table S1). The dark unzoned rim had low U (163 ppm) and Th (1 ppm) contents with low $\mathrm{Th} / \mathrm{U}$ ratios (0.01). Seventeen $\mathrm{U}-\mathrm{Th}-\mathrm{Pb}$ analyses on zircon cores and one $\mathrm{U}-\mathrm{Th}-\mathrm{Pb}$ analysis on zircon rim yielded ${ }^{207} \mathrm{~Pb} /{ }^{206} \mathrm{~Pb}$ ages of 1635 to $1720 \mathrm{Ma}$ and $145 \mathrm{Ma}$, respectively. The discordia line from zircon core and rim constrained upper and lower intercept ages at $1689.8 \pm 9.4 \mathrm{Ma}$ and $150 \pm 26 \mathrm{Ma}$, respectively (MSWD $=1.06$ ), and 16 zircon cores yielded concordance age of $1696 \pm 8.1 \mathrm{Ma}$ (MSWD = 1.8; Figure 7d). Analyses of the 16 zircon cores yielded $\varepsilon_{\mathrm{Hf}}{ }^{(\mathrm{t})}$ values ranging from -3.6 to -10.6 , with the Neoarchean $\mathrm{T}_{\mathrm{DM} 2}$ model ages ranging from 2602 to $3039 \mathrm{Ma}$ (Figure 8a,b; Table S2).

\subsection{Whole-Rock Geochemical Analyses}

The AFG samples had $67.30-72.33$ wt. $\%$ of $\mathrm{SiO}_{2}, 3.08-7.16$ wt. $\%$ of $\mathrm{Fe}_{2} \mathrm{O}_{3}{ }^{(\mathrm{t})}, 0.32-1.93$ wt. $\%$ of $\mathrm{MgO}, 11.96-13.24$ wt. $\%$ of $\mathrm{Al}_{2} \mathrm{O}_{3}, 0.59-1.88$ wt. $\%$ of $\mathrm{CaO}, 0.82-2.70$ wt. $\%$ of $\mathrm{Na}_{2} \mathrm{O}$, $4.92-7.21$ wt. $\%$ of $\mathrm{K}_{2} \mathrm{O}, 0.22-0.82 \mathrm{wt} . \%$ of $\mathrm{TiO}_{2}$, and $0.04-0.08$ wt. $\%$ of $\mathrm{MnO}$ (Table S3). In the total alkali $\left(\mathrm{Na}_{2} \mathrm{O}+\mathrm{K}_{2} \mathrm{O}\right)$ vs. $\mathrm{SiO}_{2}$ diagram (TAS diagram), the AFG was plotted in the granodiorite to granite fields (Figure 9a). The AFG samples were plotted on the high-K calc-alkaline series field, except for one sample (plotted in shoshonitic series) in the $\mathrm{K}_{2} \mathrm{O}$ vs. $\mathrm{SiO}_{2}$ diagram (Figure $9 \mathrm{~b}$ ), and had a metaluminous-to-peraluminous character (Figure 9c) with ferroan-to-magnesian compositions (Figure 9d).

The PAFG samples had 70.58-76.40 wt.\% of $\mathrm{SiO}_{2}, 1.89-3.16$ wt. $\%$ of $\mathrm{Fe}_{2} \mathrm{O}_{3}{ }^{(\mathrm{t})}, 0.07-0.85$ wt.\% of $\mathrm{MgO}, 11.43-12.83$ wt. $\%$ of $\mathrm{Al}_{2} \mathrm{O}_{3}, 0.08-1.49$ wt. $\%$ of $\mathrm{CaO}, 1.99-4.04$ wt. $\%$ of $\mathrm{Na}_{2} \mathrm{O}$, 3.58-6.25 wt.\% of $\mathrm{K}_{2} \mathrm{O}, 0.15-0.50 \mathrm{wt} . \%$ of $\mathrm{TiO}_{2}$, and $0.01-0.05 \mathrm{wt} . \%$ of $\mathrm{MnO}$ (Table S3). The PAFG plotted in the granite field in the TAS diagram is shown in Figure 9a. All the PAFG samples were plotted on the high- $\mathrm{K}$ calc-alkaline series field in the $\mathrm{K}_{2} \mathrm{O}$ vs. $\mathrm{SiO}_{2}$ diagram (Figure 9b) and had a metaluminous-to-peraluminous character (Figure 9c) with ferroan-to-magnesian compositions (Figure 9d).

In the chondrite-normalized rare earth element (REE) diagram, the AFG samples showed enrichment in light REE's $\left((\mathrm{La} / \mathrm{Yb})_{\mathrm{N}}=7.8-22.6\right.$; Figure 10a). These samples had negative $\mathrm{Eu}$ anomalies $\left(\mathrm{Eu} / \mathrm{Eu}^{*}=\mathrm{Eu}_{\mathrm{N}} / \sqrt{\mathrm{Sm}_{\mathrm{N}} * \mathrm{Gd}_{\mathrm{N}}}\right)$ ranging from 0.2 to 0.7 and also had relatively high concentrations of $\mathrm{Rb}$ (100-293 ppm), Ba (591-1874 ppm), and $\mathrm{Pb}$ (15-217 ppm; Table S3). In the primitive mantle-normalized spider diagram, the AFG samples showed enrichment in large ion-lithophile elements (e.g., $\mathrm{Rb}, \mathrm{Ba}$, and $\mathrm{K}$ ), Th, $\mathrm{U}$, $\mathrm{Pb}, \mathrm{La}, \mathrm{Ce}$, and $\mathrm{Nd}$, and negative $\mathrm{Nb}, \mathrm{Ta}, \mathrm{P}$, and Ti anomalies (Figure 10b) (Table S3). 

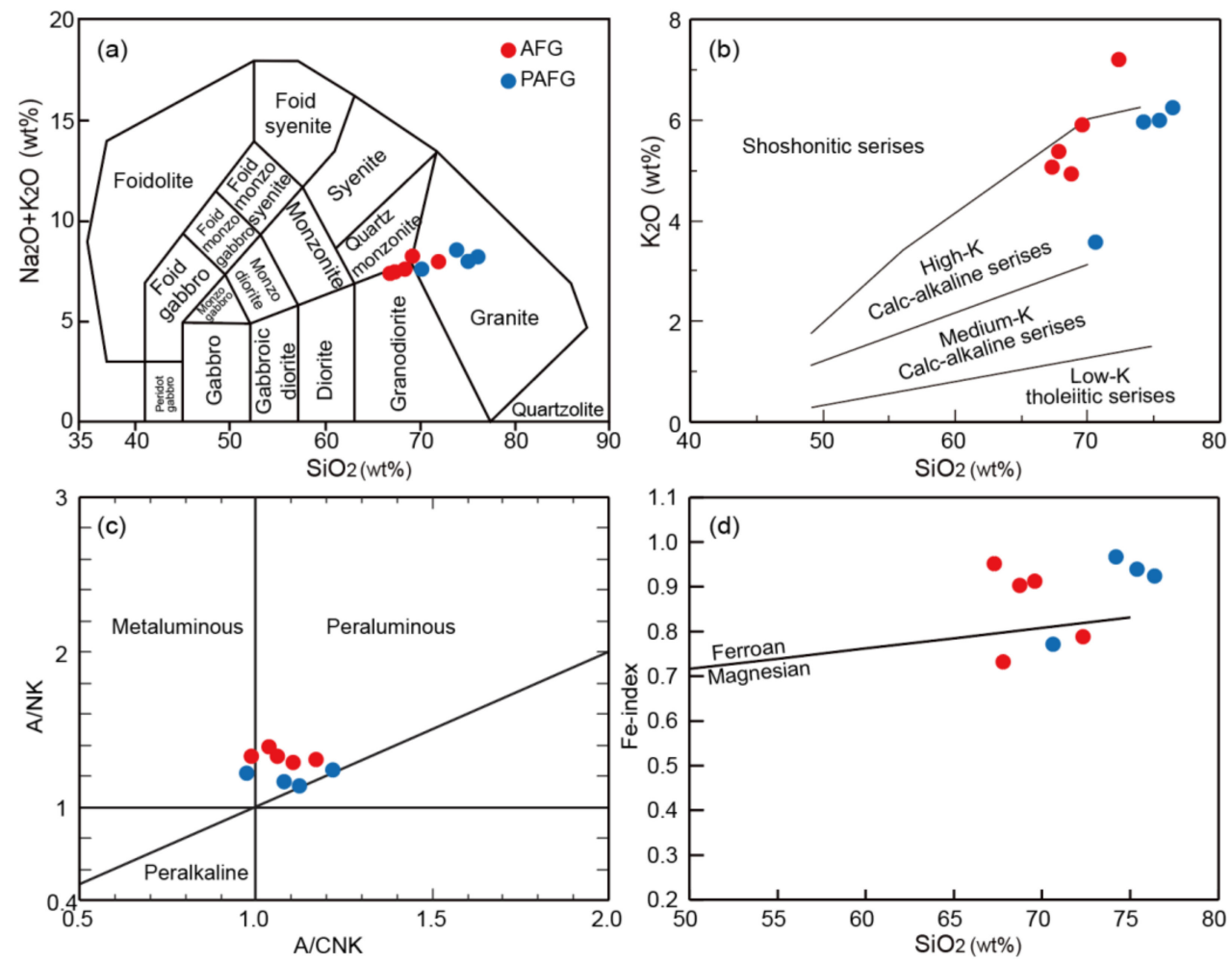

Figure 9. Geochemical classification diagrams for the Statherian granitoids. (a) Total alkali vs. $\mathrm{SiO}_{2}$

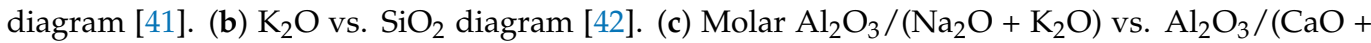
$\left.\mathrm{Na}_{2} \mathrm{O}+\mathrm{K}_{2} \mathrm{O}\right)$ diagram [43]. (d) Fe-index $\left(\left(\mathrm{FeO}^{\mathrm{t}} /\left(\mathrm{FeO}^{\mathrm{t}}+\mathrm{MgO}\right)\right)\right.$ vs. $\mathrm{SiO}_{2}$ diagram [44]. The AFG and PAFG indicate alkali feldspar granite and porphyritic alkali feldspar granite, respectively.
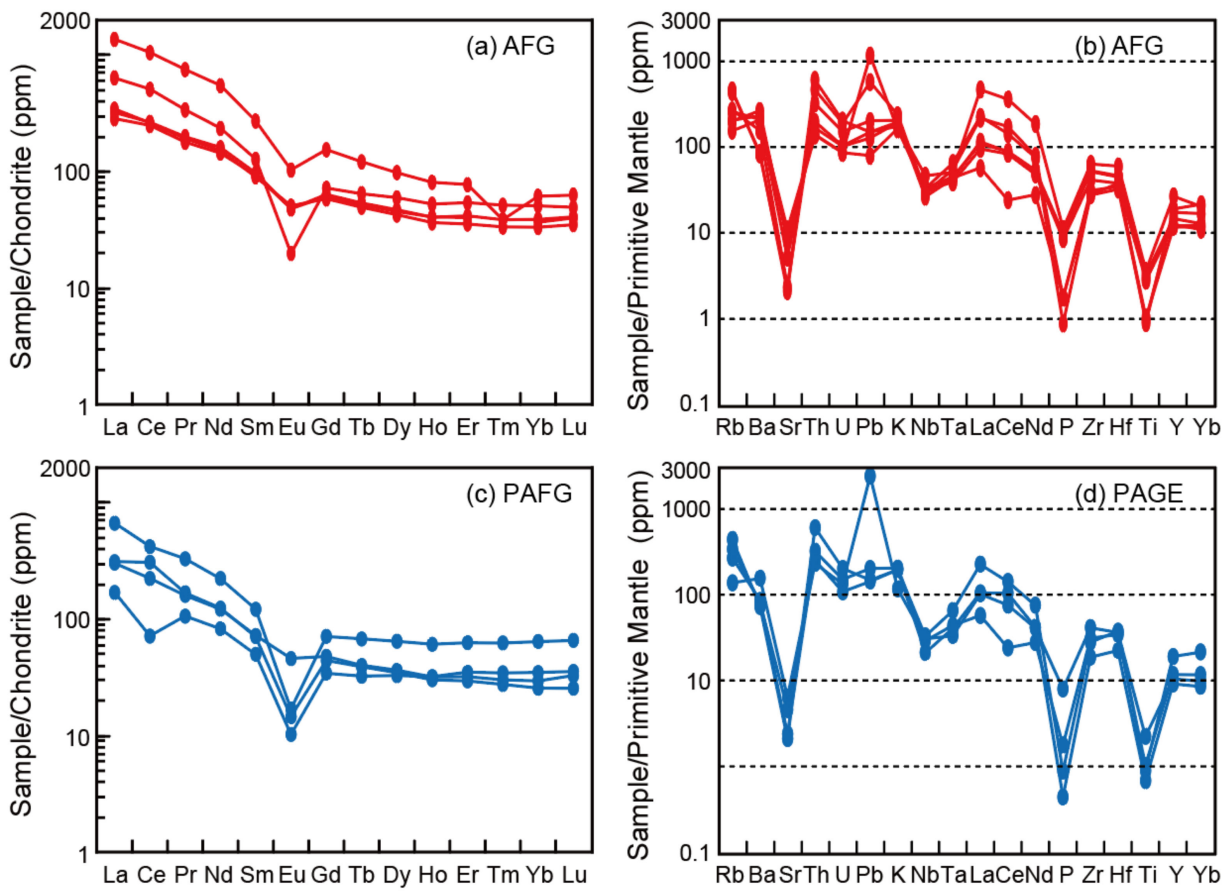

Figure 10. Chondrite-normalized rare earth elements and primitive mantle-normalized multielements diagrams for AFG $(\mathbf{a}, \mathbf{b})$ and PAFG $(\mathbf{c}, \mathbf{d})$. The chondrite and primitive mantle values are from [45]. The symbols are the same as those in Figure 9. 
In the chondrite-normalized REE diagram, the PAFG samples showed enrichment in light REE's $\left((\mathrm{La} / \mathrm{Yb})_{\mathrm{N}}=4.9-12.2\right.$; Figure 10c) with negative Eu anomalies ranging from 0.2 to 0.8 , and relatively high concentrations of $\mathrm{Rb}$ (89-282 ppm), $\mathrm{Ba}$ (521-1106 ppm), and $\mathrm{Pb}$ (28-449 ppm; Table S3). In the primitive mantle-normalized spider diagram, the foliated PAFG samples had high contents of large ion lithophile elements (e.g., $\mathrm{Rb}, \mathrm{Ba}$, and K), Th, $\mathrm{U}, \mathrm{Pb}, \mathrm{La}, \mathrm{Ce}$, and $\mathrm{Nd}$, and negative $\mathrm{Nb}, \mathrm{Ta}, \mathrm{P}$, and Ti anomalies (Figure 10d; Table S3).

\section{Discussion}

\subsection{Timing of Pluton Emplacement and Deformation}

Based on zircon $\mathrm{U}-\mathrm{Pb}$ dating and field relationships, an attempt was made to constrain the timing of magmatism and deformation in the study area. The zircon grains separated from the AFG showed oscillatory or banded zoning with high Th/U ratios (0.8-1.5), which was consistent with the characteristics of magmatic zircons [46]. These zircon grains yield a concordant age of $1.71 \mathrm{Ga}(1714 \pm 12 \mathrm{Ma}$ and $1707 \pm 6.1 \mathrm{Ma}$; Figure $7 \mathrm{a}, \mathrm{b})$, indicating the AFG emplacement at $1.71 \mathrm{Ga}$. The zircon grains separated from the PAFG had typomorphic and compositional characteristics similar to those of the zircon grains from the AFG (Figure 6 and Table S1). These zircon grains yield a concordant age of 1.70-1.68 Ga $(1696 \pm 8.1 \mathrm{Ma}$ and $1680 \pm 4.0 \mathrm{Ma}$; Figure 7c,d) that was interpreted as the emplacement age. Although the youngest and oldest emplacement ages of the AFG and PAFG overlapped within the error range, their field relationships, wherein the PAFG intruded the AFG, indicated that the AFG formed before PAFG [17].

The AFG and PAFG underwent regional ductile shearing, which was recorded by the development of the regional mylonitic fabric. The onset of ductile shearing can easily be constrained by the crosscutting relationship between AFG and PAFG. The weakly foliated PAFG crosscut the strong mylonitic foliation of the AFG, indicating that the AFG was strongly deformed before the emplacement of the PAFG. The results of zircon $\mathrm{U}-\mathrm{Pb}$ dating showed that the main ductile shearing in the AFG could have occurred between $1707 \pm 6.1 \mathrm{Ma}$ and $1696 \pm 8.1 \mathrm{Ma}$. Although the timing of the deformation of the PAFG was not constrained, it was assumed that it might have occurred soon after its emplacement. However, further studies are needed to verify the timing of deformation of the PAFG.

\subsection{Genetic Type and Source Material of the AFG and PAFG}

As mentioned earlier, AFG and PAFG underwent ductile deformation. In addition, zircons in the AFG and PAFG have recrystallized rims that show dim and unzoned textures (Figure 6). Thus, the element mobility of the AFG and PAFG needs to be examined before discussing petrogenesis using whole-rock geochemical compositions. The silicic or carbonatic alteration was not observed in AFG and PAFG. The losses on ignition of the AFG and PAFG were 0.96-1.59 and 0.48-1.82, respectively. The $\mathrm{Ce}^{*}\left(\mathrm{Ce}^{*}=\mathrm{Ce}_{\mathrm{N}} / \sqrt{\mathrm{La}_{\mathrm{N}} * \operatorname{Pr}_{\mathrm{N}}}\right)$ values of the AFG and PAFG were 1.0-1.1 and 0.9-1.0, respectively. This information indicates that the whole-rock compositions could be used to constrain the petrogenesis and source material of the AFG and PAFG. However, the two PAFG samples (TD13 and GS1) had distinct $\mathrm{Ce}^{*}$ values $(0.5,1.3)$, implying that some mobile elements (e.g., Sr) might have been modified during deformation. Thus, the mobile elements in the TD13 and GS1 samples are not considered in the discussion of petrogenesis.

The whole-rock geochemical analyses showed that the AFG had granodioritic to granitic compositions, while PAFG had granitic compositions (Table S3). Both rock types had high contents of $\mathrm{K}_{2} \mathrm{O}, \mathrm{K}_{2} \mathrm{O}+\mathrm{Na}_{2} \mathrm{O}, \mathrm{Nb}, \mathrm{Ta}, \mathrm{Y}, \mathrm{Zr}$, and light REEs with alkali-calcic and ferroan characteristics contrasting with low contents of $\mathrm{Al}_{2} \mathrm{O}_{3}, \mathrm{CaO}$, and $\mathrm{Ba}$. They also had high $\mathrm{Nb}+\mathrm{Y}(>60)$ content with high $\mathrm{FeO}^{\mathrm{t}} / \mathrm{MgO}$ and $\mathrm{Ga} / \mathrm{Al}$ ratios. These parameters indicated A-type rather than I- or S-type affinities [47-49]. In addition, both the AFG and PAFG were plotted in the A-type field in the granite classification diagram and had higher zircon saturation temperatures $\left(\mathrm{T}_{\mathrm{zr}}{ }^{\circ} \mathrm{C}=820-932{ }^{\circ} \mathrm{C}\right)$ than the average zircon saturation temperature of A-type granite (Figure 11d) [50]. Based on the ratios of incompatible elements, A-type granite was subdivided into $\mathrm{A}_{1}$ - and $\mathrm{A}_{2}$-types and these were considered 
to have formed in an anorogenic and post-collisional tectonic setting, respectively [51]. In the A-type granite subdivision diagram, the AFG and PAFG were plotted in the $\mathrm{A}_{2}$-type field, indicating that they formed in the post-collision tectonic setting (Figure 11). The subdivision of $\mathrm{A}_{1}$ - and $\mathrm{A}_{2}$-type granites should only be used for granitoids that were plotted in the A-type granite field suggested in [47] and the within-plate granite field suggested in [52]. This was the case of the AFG and PAFG granites, thus supporting the $\mathrm{A}_{2}$-type affinity (Figure 12).
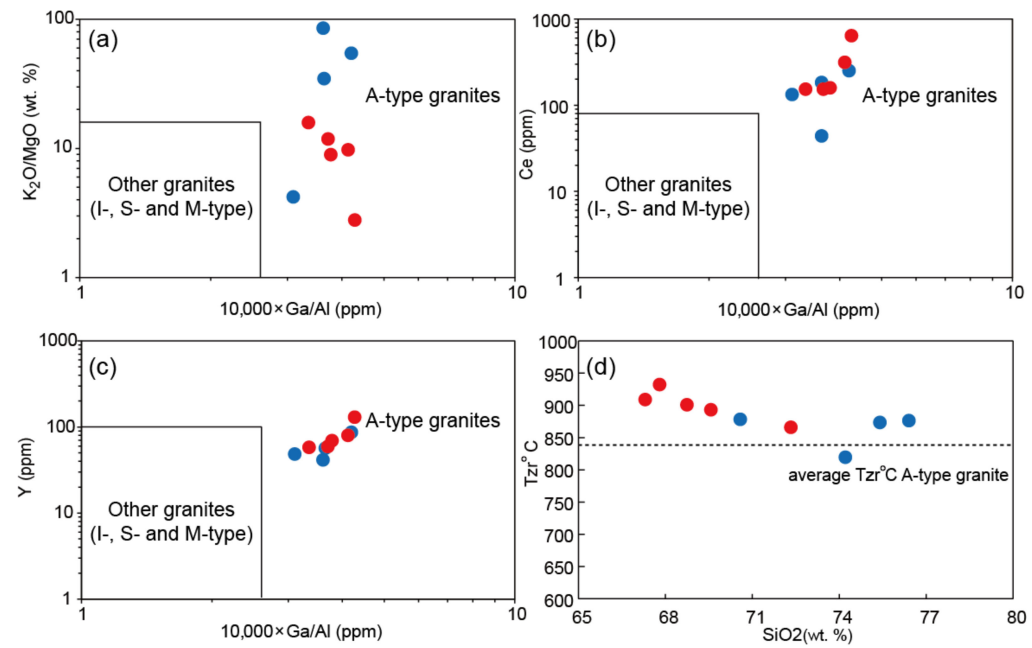

Figure 11. (a-c) Genetic discrimination diagram for the Statherian granitoids [47]. (d) Zircon saturation temperature $\left(T_{\mathrm{zr}}{ }^{\circ} \mathrm{C}=\mathrm{In} D_{\mathrm{Zr}}\right.$ zircon/melt $--3.80-[0.85(M-1)]+12,900 / T$ suggested by [53]) vs. $\mathrm{SiO}_{2}$ diagram, $\mathrm{D}_{\mathrm{Zr}}$ zircon/melt — the concentration ratio of $\mathrm{Zr}$ in the stoichiometric zircon to that in the melt, $\mathrm{M}$ - the cation ration $(\mathrm{Na}+\mathrm{K}+2 \mathrm{Ca}) /\left(\mathrm{Al}{ }^{*} \mathrm{Si}\right), \mathrm{T}$ - the absolute temperature. The average zircon saturation temperature for A-type granite was taken from [50]. The symbols are the same as those in Figure 9.
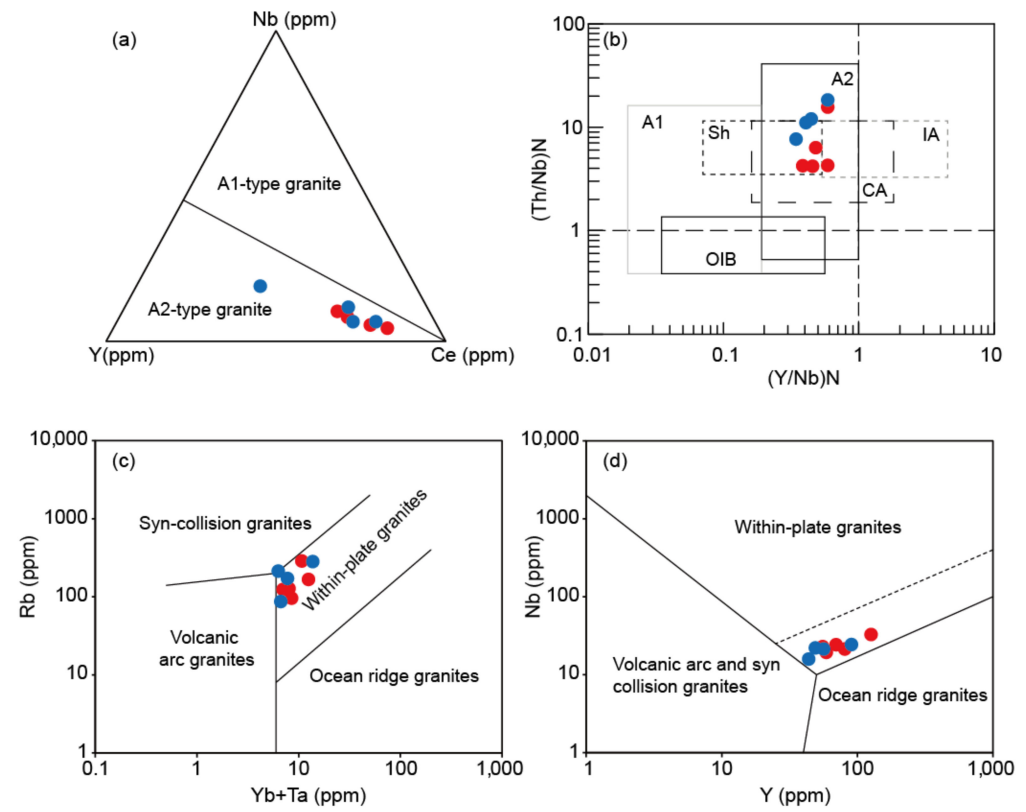

Figure 12. (a) Subdivision diagram for A-type granites [46]. (b) $(\mathrm{Th} / \mathrm{Nb})_{\mathrm{N}}$ and $(\mathrm{Y} / \mathrm{Nb})_{\mathrm{N}}$ diagram for subdivision of A-type granites [52]. (c) $\mathrm{Rb}$ versus $\mathrm{Yb}+\mathrm{Ta}$ tectonic discrimination diagram [51]. (d) $\mathrm{Nb}$ versus $\mathrm{Y}$ tectonic discrimination diagram [51]. Abbreviations: A1-A1-type granitoids, A2-A2type granitoids, Sh—shoshonites, IA-Island Arcs, CA-Continental Arcs, OIB-Ocean Island Basalts. Normalization $(\mathrm{N})$ value of silicate earth after [54]. The symbols are the same as those in Figure 9. 
The source material and genetic process of A-type granitoids have long been discussed. In case of the $\mathrm{A}_{2}$-type granitoids, there are three possible source materials as follows: (1) mantle-derived mafic melt, (2) crust-derived melt, and (3) mixing or assimilation between mantle- and crust-derived melts $[51,55,56]$. The zircon separated from the AFG and PAFG yielded negative $\varepsilon_{\mathrm{Hf}}{ }^{(\mathrm{t})}$ values ranging from -3.5 to -8.1 for the AFG and from -3.6 to -10.6 for the PAFG with the $\mathrm{T}_{\mathrm{DM} 2}$ model age (2775 Ma on average) much older than the emplacement age (Table S2). This indicates that the source material for the AFG and PAFG was derived from ancient crustal material, excluding the mantle-derived melt. In summary, the geochemical analysis shows that the granitoids originated from the reworked ancient crustal material in an extension-related, post-collisional setting.

\subsection{Implication of the Statherian Events in the Korean Peninsula}

Based on the geochemical and geochronological analyses, it was revealed that the granitoids in the southwestern region of the Korean Peninsula formed in an extension-related setting during the Statherian (1.71-1.68 Ga). The extension-related setting was also confirmed by the development of the dextral strike-slip with a minor extensional component (a southeast side up) on the foliated AFG and the emplacement of the foliated PAFG in a syntectonic setting. In terms of geochemical composition, these Statherian granitoids could be well correlated with the granitic gneiss and anatectic granite of the midwestern part of the Korean Peninsula (the western Gyeonggi Massif or the Hongseong-Imjingang Belt) [9]. The rocks in both areas were classified as A-type granitoids based on the high contents of alkalis $\left(\mathrm{K}_{2} \mathrm{O}\right.$ and $\left.\mathrm{Na}_{2} \mathrm{O}\right)$, light $\mathrm{REEs}, \mathrm{Nb}+\mathrm{Y}$, and high $\mathrm{FeO}^{\mathrm{t}} / \mathrm{MgO}$ and $\mathrm{Ga} / \mathrm{Al}$ ratios. Both rock types also had similar zircon Lu-Hf isotopic compositions, with $\varepsilon_{\mathrm{Hf}}{ }^{(\mathrm{t})}$ values ranging from -3.6 to -17.8 (Figure 8a). In addition, the biotite granite in the northwestern part of the Korean Peninsula (Uiju area in the northwestern part of the Nangnim Massif) also had an emplacement age of $1654 \pm 79 \mathrm{Ma}$, similar to granitoids and granitic gneiss in the midwestern to the southwestern part of the Korean Peninsula [16]. Although there were no geochemical data, it was assumed that this biotite granite also formed in an extensional setting because of the similarity in emplacement age and the Orosirian tectonothermal events in the Nangnim and Gyeonggi massifs. The data indicate that there were regional extension-related magmatic events accompanying the ductile deformation along the western part of the Korean Peninsula during 1.71-1.68 Ga. The Statherian granitoids of the western part of the Korean Peninsula had geochemical compositions that were similar to the granite formed in a post-collisional setting (Figures 11 and 12) [9]. Thus, the Statherian extension occurred in a post-collisional setting. Considering that the basement of the Korean Peninsula underwent orogenic magmatism, metamorphism, and deformation during 1.93-1.78 Ga [20,21,24,57-59], the Statherian post-collisional magmatism in the western part of the Korean Peninsula might have followed the Orosirian orogenic events.

As mentioned earlier, the Statherian extension occurred in the eastern part of the NCC and the Yangtze Block in the South China Craton during 1.74-1.63 Ga, but their tectonic setting was different. In general, it is considered that the Statherian events in the eastern part of the NCC occurred in a post-collisional setting that followed the collision of the eastern and western blocks of the NCC [8 and references therein]. On the other hand, the extension in the southwestern part of the Yangtze Block occurred in the continental rifting regime [40,60], although a subduction setting has also been suggested [61]. Recently, [62] suggested that continental rifting occurred in the northern margin of the Yangtze Block (in the region of the Tongbai orogeny) at ca. $1.63 \mathrm{Ga}$, and these events could be correlated well with the continental rifting in the southwestern part of the Yangtze Block, indicating continental rifting as the dominant setting of the Yangtze Block during ca. 1.74-1.63 Ga. The petrogenesis of the Statherian granitoids in the eastern part of the NCC was also different from that of the Statherian granitoids of the Yangtze Block. In general, most of the Statherian granitoids in the eastern part of the NCC are formed by partial melting of the ancient crust [8], but the Statherian granitoids in the Yangtze Block are formed by fractional crystallization of the juvenile mafic magma [40]. 
As previously mentioned, the Statherian granitoids in the southwestern part of the Korean Peninsula had geochemical compositions that were similar to those of post-collisional granites. The zircon Lu-Hf isotopic compositions showed that the Statherian granitoids originated from ancient crustal material that might have formed during the Neoarchean (Figure 8). These geochemical and isotopic characteristics correlated well with the Statherian granitoids in the eastern part of the NCC. Recently, a comparison of the geochemical compositions of the Statherian granitoids in the midwestern part of the Korean Peninsula, the eastern part of the NCC, and southwestern part of the Yangtze Block was made [9]. It was also concluded that the Statherian granitoids on the Korean Peninsula are better correlated with those of the eastern part of the NCC than with those of the Yangtze Block. For example, the Statherian granitoids in the midwestern part of the Korean Peninsula and eastern NCC have distinctly lower $(\mathrm{Nb} / \mathrm{La})_{\mathrm{N}},(\mathrm{Th} / \mathrm{Nb})_{\mathrm{N}}$, and $(\mathrm{Ta} / \mathrm{La})_{\mathrm{N}}$ ratios than the Statherian granitoids of the Yangtze Block. Thus, we propose that the western part of the Korean Peninsula (in present coordinates) might have undergone regional, extensionrelated magmatism during the Statherian (1.71-1.68 Ga), which is similar to that in the eastern part of the NCC.

\section{Conclusions}

(1) The SHRIMP zircon U-Pb dating revealed that the foliated AFG and PAFG were emplaced in the southwestern extreme of the Korean Peninsula at $1.71 \mathrm{Ga}$ and $1.70-1.68 \mathrm{Ga}$, respectively.

(2) The zircon Lu-Hf isotope and the whole-rock geochemical analyses suggested that the foliated AFG and PAFG were possibly derived from the reworked ancient crustal material and formed in a post-collisional setting.

(3) The structural analysis showed that the foliated AFG underwent ductile deformation converting into protomylonite, mylonite, or ultramylonite. The mylonitic foliation stroke NE-ENE and dipped to NW. The foliated PAFG was weakly deformed in a ductile regime and characterized by very thin ultramylonite zones having a width of few millimeters. Asymmetric structures (e.g., S-C fabric) indicated a dextral sense of movement with minor extension.

(4) Based on field relationship and zircon U-Pb dating, it could be concluded that the ductile deformation might have been initiated after emplacement of the AFG and terminated soon after emplacement of the foliated PAFG.

(5) The Statherian igneous activities in the region of the southwestern part of the Korean Peninsula could be well correlated with those occurring in the midwestern Gyeonggi Massif and in the eastern NCC.

Supplementary Materials: The following are available online at https:/ / www.mdpi.com/article/10 $.3390 / \min 11060557 / \mathrm{s} 1$, Table S1: The SHRIMP zircon age data of the foliated alkali feldspar granite and foliated porphyritic alkali feldspar granite in the region of Taedo-Ganseodo, Table S2: Zircon Lu-Hf analysis for the foliated alkali feldspar granite and foliated porphyritic alkali feldspar granite in the region of Taedo-Ganseodo, Table S3: Whole-rock compositions of the foliated alkali feldspar granite and foliated porphyritic alkali feldspar granite in the region of the Taedo-Ganseodo.

Author Contributions: Conceptualization, data acquisition, writing-original draft, review and editing, visualization, B.C.L.; data acquisition, writing - original draft, review and editing, W.-S.K.; data acquisition, visualization and review, U.H.B.; visualization and review, S.W.K. All authors have read and agreed to the published version of the manuscript.

Funding: This work was financially supported by grants from the Korea Institute of Geoscience and Mineral Resources (GP2020-003), funded by the Ministry of Science and Information, Communication, and Technology.

Data Availability Statement: Data are contained within the article and Tables S1-S3. 
Acknowledgments: The authors would like to thank five anonymous reviewers who helped to improve the manuscript. The authors also would like to thank Youn-Joong Jeong from the KBSI Ochang Center for the help with the zircon Lu-Hf analysis.

Conflicts of Interest: The authors declare no conflict of interest.

\section{References}

1. Wilson, J.T. Did the atlantic close and then re-open? Nature 1966, 211, 676-681. [CrossRef]

2. Zhao, G.; Zhai, M. Lithotectonic elements of Precambrian basement in the North China Craton: Review and tectonic implications. Gondwana Res. 2013, 23, 1207-1240. [CrossRef]

3. Xu, W.; Liu, F. Geochronological and geochemical insights into the tectonic evolution of the Paleoproterozoic Jiao-Liao-Ji Belt, Sino-Korean Craton. Earth-Sci. Rev. 2019, 193, 162-198.

4. Hoernle, K.; Schaefer, B.; Li, S.; Hauff, F.; Li, X.; Garbe-Schönberg, D.; Zhang, R.; Liu, Y. 2.8-1.7 Ga history of the Jiao-Liao-Ji Belt of the North China Craton from the geochronology and geochemistry of mafic Liaohe meta-igneous rocks. Gondwana Res. 2020, 85, 55-75. [CrossRef]

5. Liu, J.; Zhang, J.; Liu, Z.; Yin, C.; Xu, Z.; Cheng, C.; Zhao, C.; Wang, X. Late Paleoproterozoic crustal thickening of the Jiao-Liao-Ji belt, North China Craton: Insights from ca. 1.95-1.88 Ga syn-collisional adakitic granites. Precambrian Res. 2021, 355, 106120. [CrossRef]

6. Wang, X.; Peng, P.; Wang, C.; Yang, S. Petrogenesis of the 2115Ma Haicheng mafic sills from the Eastern North China Craton: Implications for an intra-continental rifting. Gondwana Res. 2016, 39, 347-364. [CrossRef]

7. Wang, X.; Oh, C.W.; Lee, B.C.; Liu, F.L. Paleoproterozoic postcollisional metamorphic and igneous activities in the Jinan area of the Jiao-Liao-Ji Belt in the North China Craton and their tectonic implications. Precambrian Res. 2020, 346, 105793. [CrossRef]

8. Wang, Y.; Yang, Y.; Siebel, W.; Zhang, H.; Zhang, Y.; Chen, F. Geochemistry and tectonic significance of late Paleoproterozoic A-type granites along the southern margin of the North China Craton. Sci. Rep. 2020, 10, 86. [CrossRef] [PubMed]

9. Kim, J.; Choi, S.H. Petrogenesis and tectonic implications of the late Paleoproterozoic (ca. $1.7 \mathrm{Ga}$ ) post-collisional magmatism in the southwestern Gyeonggi Massif at Garorim Bay, South Korea. J. Asian Earth Sci. X 2021, 5, 100050.

10. Jiang, N.; Guo, J.; Zhai, M. Nature and origin of the Wenquan granite: Implications for the provenance of Proterozoic A-type granites in the North China craton. J. Asian Earth Sci. 2011, 42, 76-82. [CrossRef]

11. Wang, W.; Liu, S.; Bai, X.; Li, Q.; Yang, P.; Zhao, Y.; Zhang, S.; Guo, R. Geochemistry and zircon U-Pb-Hf isotopes of the late Paleoproterozoic Jianping diorite-monzonite-syenite suite of the North China Craton: Implications for petrogenesis and geodynamic setting. Lithos 2013, 162-163, 175-194. [CrossRef]

12. Li, Y.; Peng, P.; Wang, X.; Wang, H. Nature of 1800-1600 Ma mafic dyke swarms in the North China Craton: Implications for the rejuvenation of the sub-continental lithospheric mantle. Precambrian Res. 2015, 257, 114-123. [CrossRef]

13. Wang, X.; Wang, T.; Castro, A.; Ke, C.; Yang, Y.; Hu, N. Magmatic evolution and source of a Proterozoic rapakivi granite complex in the North China Craton: New evidence from zircon $\mathrm{U}-\mathrm{Pb}$ ages, mineral compositions, and geochemistry. J. Asian Earth Sci. 2018, 167, 165-180. [CrossRef]

14. He, H.; Song, X.; Zhai, M.; Yu, S.; Du, Z. Lower crustal contribution to the magma formation of the Damiao massif type anorthosite, North China Craton: Evidence from zircon Hf-O isotopes. Precambrian Res. 2019, 332, 105396. [CrossRef]

15. Zhao, T.; Zhou, M. Geochemical constraints on the tectonic setting of Paleoproterozoic A-type granites in the southern margin of the North China Craton. J. Asian Earth Sci. 2009, 36, 183-195. [CrossRef]

16. Wu, F.; Han, R.; Yang, J.; Wild, A.S.; Zhai, M.; Park, S. Initial constraints on the timing of granitic magmatism in North Korea using U-Pb zircon geochronology. Chemical Geology 2007, 238, 232-248. [CrossRef]

17. Kee, W.-S.; Lee, B.C.; Byun, U.H. Geological Report of the Taedo Manjaedo Gansedo Gageodo Sheets, 1:50,000 Scale; Korea Institute of Geoscience and Mineral Resources: Daejeon, Korea, 2020.

18. Kee, W.-S.; Kim, S.W.; Kim, H.; Hong, P.; Kwon, C.W.; Lee, H.-J.; Cho, D.-L.; Koh, H.J.; Song, K.-Y.; Byun, U.H.; et al. Geologic Map of Korea (Scale 1:1,000,000); Korea Institute of Geoscience and Mineral Resources: Daejeon, Korea, 2019.

19. Zhao, L.; Zhai, M.; Nutman, A.P.; Oh, C.W.; Bennett, V.C.; Zhang, Y. Archean basement components and metamorphic overprints of the Rangnim Massif in the northern part of the Korean Peninsula and tectonic implications for the Sino-Korean Craton. Precambrian Res. 2020, 344, 105735. [CrossRef]

20. Lee, B.C.; Oh, C.W.; Yi, K. Geochemistry, zircon U-Pb ages, and Hf isotopic compositions of Precambrian gneisses in the Wonju-Jechon area of the southern Gyeonggi Massif: Implications for the Precambrian tectonic evolution of Korea and northeast Asia. Precambrian Res. 2016, 283, 169-189. [CrossRef]

21. Lee, B.C.; Park, J.H.; Oh, C.W.; Yi, K. Metamorphic and magmatic evolution of the Paleoproterozoic gneisses in the Sancheong area, Yeongnam Massif, South Korea, and their implications to the tectonics in the Northeast Asia. Precambrian Res. 2017, 298, 439-461. [CrossRef]

22. Lee, B.C.; Oh, C.W.; Cho, D.; Yi, K. Paleoproterozoic (2.0-1.97 Ga) subduction-related magmatism on the north-central margin of the Yeongnam Massif, Korean Peninsula, and its tectonic implications for reconstruction of the Columbia supercontinent. Gondwana Res. 2019, 72, 34-53. [CrossRef] 
23. Cho, D.; Lee, B.C.; Oh, C.W. Petrogenesis of paleoproterozoic (2.02-1.96 Ga) metagranitoids in the southwestern Yeongnam Massif, Korean Peninsula, and their significance for the tectonic history of northeast Asia: Insights from zircon $\mathrm{U}-\mathrm{Pb}-\mathrm{Hf}$ isotope and whole-rock geochemical compositions. Precambrian Res. 2020, 340, 105631.

24. Lee, B.C.; Oh, C.W.; Yengkhom, K.S.; Yi, K. Paleoproterozoic magmatic and metamorphic events in the Hongcheon area, southern margin of the Northern Gyeonggi Massif in the Korean Peninsula, and their links to the Paleoproterozoic orogeny in the North China Craton. Precambrian Res. 2014, 248, 17-38. [CrossRef]

25. Lee, Y.; Cho, M.; Cheong, W.; Yi, K. Prolonged high-temperature, low-pressure metamorphism associated with $~ 1.86$ Ga Sancheong-Hadong anorthosite in the Yeongnam Massif, Korea: Paleoproterozoic hot orogenesis in the North China Craton. Precambrian Res. 2018, 307, 175-200. [CrossRef]

26. Lee, B.C.; Oh, C.W.; Wang, X. Paleoproterozoic (ca. 1.87-1.69 Ga) arc-related tectonothermal events on North central Yeongnam Massif, South Korea and its tectonic implications: Insights from metamorphism, geochemistry and geochronology. Precambrian Res. 2020, 338, 105562. [CrossRef]

27. Oh, C.W.; Lee, B.C.; Yi, S.; Ryu, H.I. Correlation of Paleoproterozoic igneous and metamorphic events of the Korean Peninsula and China; Its implication to the tectonics of Northeast Asia. Precambrian Res. 2019, 326, 344-362. [CrossRef]

28. Cho, D.; Kim, Y.; Armstrong, R. SHRIMP U-Pb Geochronology of Detrital Zircons from Iron-bearing Quartzite of the Seosan Group: Constraints on Age and Stratigraphy. J. Petrol. Soc. Korea 2006, 15, 119-127.

29. Kim, S.W.; Kee, W.S.; Santosh, M.; Cho, D.; Hong, P.S.; Ko, K.; Lee, B.C.; Byun, U.H.; Jang, Y. Tracing the Precambrian tectonic history of East Asia from Neoproterozoic sedimentation and magmatism in the Korean Peninsula. Earth-Sci. Rev. 2020, 209, 103311. [CrossRef]

30. Stacey, J.S.; Kramers, J.D. Approximation of terrestrial lead isotope evolution by a two-stage model. Earth Planet. Sci. Lett. 1975, 26, 207-221. [CrossRef]

31. Williams, I.S. U-Th-Pb geochronology by ion microprobe. In Applications of Microanalytical Techniques to Understanding Mineralizing Processes; Mckibben, M.A., Shanks, W.C., Eds.; Society of Economic Geologists: Littleton, CO, USA, 1998; pp. 1-35.

32. Ludwig, K.R. SQUID 2: A User's Manual. Berkeley Geochronol. Cent. Spec. Publ. 2009, 5, 110.

33. Söderlund, U.; Patchett, P.J.; Vervoort, J.D.; Isachsen, C.E. The 176Lu decay constant determined by Lu-Hf and U-Pb isotope systematics of Precambrian mafic intrusions. Earth Planet. Sci. Lett. 2004, 219, 311-324. [CrossRef]

34. Blichert-Toft, J.; Albarède, F. The Lu-Hf isotope geochemistry of chondrites and the evolution of the mantle-crust system. Earth Planet. Sci. Lett. 1997, 148, 243-258. [CrossRef]

35. Griffin, W.L.; Wang, X.; Jackson, S.E.; Pearson, N.J.; O’Reilly, S.Y.; Xu, X.; Zhou, X. Zircon chemistry and magma mixing, SE China: In situ analysis of Hf isotopes, Tonglu and Pingtan igneous complexes. Lithos 2002, 61, 237-269. [CrossRef]

36. Amelin, Y.; Lee, D.C.; Halliday, A.N.; Pidgeon, R.T. Nature of the Earth's earliest crust from hafnium, isotopes in single detrital zircons. Nature 1999, 399, 252-255. [CrossRef]

37. Dhuime, B.; Hawkesworth, C.; Cawood, P. When continents formed. Science 2011, 331, 154-155. [CrossRef] [PubMed]

38. Griffin, W.L.; Pearson, N.J.; Belousova, E.A.; Jackson, S.E.; O’Reilly, S.Y.; van Achterberg, E.; Shee, S.R. The Hf isotope composition of cratonic mantle: LAM-MC-ICPMS analysis of zircon megacrysts in kimberlites. Geochim. Cosmochim. Acta 2000, 64, 133-147. [CrossRef]

39. Liu, K.; Lu, G.; Wang, Z.; Huang, S.; Xue, E.; Wang, W. The Paleoproterozoic bimodal magmatism in the SW Yangtze block: Implications for initial breakup of the Columbia supercontinent. Lithos 2019, 332-333, 23-38. [CrossRef]

40. Geng, Y.; Du, L.; Kuang, H.; Liu, Y. Ca. 1.7 Ga Magmatism on Southwestern Margin of the Yangtze Block: Response to the Breakup of Columbia. Acta Geol. Sin. 2020, 94, 2031-2052.

41. Middlemost, E.A. Naming materials in the magma/igneous rock system. Earth-Sci. Rev. 1997, 37, 215-224. [CrossRef]

42. Peccerillo, A.; Taylor, S.R. Geochemistry of Eocene calc-alkaline volcanic rocks of the Kastamonu area northern turkey. Contrib. Mineral. Petrol. 1976, 31, 58-63. [CrossRef]

43. Maniar, P.D.; Piccoli, P.M. Tectonic discrimination of granitoids. Geol. Soc. Am. Bull. 1989, 101, 635-643. [CrossRef]

44. Frost, B.R.; Barnes, C.G.; Collins, W.J.; Arculus, R.J.; Ellis, D.J.; Frost, C.D. A geochemical classification for granitic rocks. J. Petrol. 2001, 42, 2033-2048. [CrossRef]

45. Sun, S.S.; McDonough, W.F. Chemical and isotopic systematics of oceanic basalts: Implications for mantle composition and process. Geol. Soc. Lond. Spec. Publ. 1989, 42, 313-345. [CrossRef]

46. Hoskin, P.W.O.; Schaltegger, U. The composition of Zircon and Igneous and Metamorphic Petrogenesis. Rev. Mineral. Geochem. 2003, 53, 27-62. [CrossRef]

47. Whalen, J.B.; Currie, K.L.; Chappell, B.W. A-type granites: Geochemical characteristics, discrimination and petrogenesis. Contrib. Mineral. Petrol. 1987, 95, 407-419. [CrossRef]

48. Bonin, B. A-type granites and related rocks: Evolution of a concept, problems and prospects. Lithos 2007, 97, 1-29. [CrossRef]

49. Whalen, J.B.; Hildebrand, R.S. Trace element discrimination of arc, slab failure, and A-type granitic rocks. Lithos 2019, 348-349, 105179. [CrossRef]

50. King, P.L.; White, A.J.R.; Chappell, B.W.; Allen, C.M. Characterization and origin of aluminous A-type granites from the Lachlan Fold Belt, southeastern Australia. J. Petrol. 1997, 38, 371-391. [CrossRef]

51. Eby, G.N. Chemical subdivision of the A-type granitoids: Petrogenetic and tectonic implications. Geology 1992, $20,641-644$. [CrossRef] 
52. Pearce, J.A.; Harris, N.B.W.; Tindle, A.G. Trace element discrimination diagrams for the tectonic interpretation of granitic rocks. J. Petrol. 1984, 25, 956-983. [CrossRef]

53. Watson, E.B.; Harrison, M. Zircon saturation revisited: Temperature and composition effects in a variety of crustal magma types. Earth Planet. Sci. Lett. 1983, 64, 295-304. [CrossRef]

54. McDonough, W.F.; Sun, S.S. The composition of the Earth. Chem. Geol. 1995, 120, 223-253. [CrossRef]

55. Kemp, A.I.S.; Hawkesworth, C.J.; Paterson, B.A.; Kinny, P.D. Episodic growth of the Gondwana supercontinent from hafnium and oxygen isotopes in zircon. Nature 2006, 439, 580-583. [CrossRef] [PubMed]

56. Moreno, J.A.; Molina, J.F.; Montero, P.; Anbar, M.A.; Scarrow, J.H.; Cambeses, A.; Bea, F. Unraveling sources of A-type magmas in juvenile continental crust: Constraints from compositionally diverse Ediacaran post-collisional granitoids in the Katerina Ring Complex, southern Sinai, Egypt. Lithos 2014, 192-195, 56-85. [CrossRef]

57. Zhao, L.; Zhang, Y.B.; Wu, F.Y.; Li, Q.L.; Yang, J.H.; Kim, J.N.; Choi, W.J. Paleoproterozoic high temperature metamorphism and anataxis in the northwestern Korean Peninsula: Constraints from petrology and zircon U-Pb geochronology. Acata Petrol. Sin. 2016, 32, 3045-3069.

58. Yengkhom, K.S.; Lee, B.C.; Oh, C.W.; Yi, K. Tectonic and deformation history of the Gyeonggi Massif in andaround the Hongcheon area, and its implications in the tectonicevolution of the North China Craton. Precambrian Res. 2014, 240, 37-59. [CrossRef]

59. Li, Q.L.; Zhao, L.; Zhang, Y.B.; Yang, J.H.; Kim, J.N.; Han, R.H. Zircon-titanite-rutile U-Pb system from metamorphic rocks of Jungshan Group in Korea: Implications of tectono-thermal events from Paleoproterozoic to Mesozoic. Acta Petrol. Sin. 2016, 32, 3019-3032.

60. Zhao, X.; Zhou, M.; Li, J.; Sun, M.; Gao, J.; Sun, W.; Yang, J. Late Paleoproterozoic to early Mesoproterozoic Dongchuan Group in Yunnan, SW China: Implications for tectonic evolution of the Yangtze Block. Precambrian Res. 2010, 182, 57-69. [CrossRef]

61. Zhu, Z.; Tan, H.; Liu, Y. Late Palaeoproterozoic Hekou Group in Sichuan, Southwest China: Geochronological framework and tectonic implications. Int. Geol. Rev. 2018, 60, 305-318. [CrossRef]

62. Zhang, Q.; Gao, X.; Zhang, S.; Zheng, Y. Paleoproterozoic tectonic evolution of the northern Yangtze craton from oceanic subduction through continental collision to continental rifting: Geochronological and geochemical records of metabasites from the Tongbai orogen in central China. Precambrian Res. 2020, 350, 105920. [CrossRef] 